\title{
Microbiological and Physicochemical Assessment of Soil Contaminated with Lairage Effluent in Umuahia, Abia State, Nigeria.
}

\author{
${ }^{1}$ Eze, Vincent Chukwuemeka, ${ }^{2}$ Omeh, Yusuf Ndukaku and ${ }^{3}$ Ugweje, Chinenye \\ Danielle \\ ${ }^{I}$ Department of Microbiology, Michael Okpara University of Agriculture Umudike, Abia State, Nigeria. \\ ${ }^{2}$ Department of Biochemistry, Michael Okpara University of Agriculture Umudike, Abia State, Nigeria. \\ ${ }^{3}$ Department of Microbiology, Michael Okpara University of Agriculture Umudike, Abia State, Nigeria.
}

\begin{abstract}
The microbiological and physicochemical characteristics of soil contaminated with lairage effluent were investigated. A total of twenty samples were analyzed for total heterotrophic bacterial count, fungal count, Vibrio cholerae count, Salmonella-Shigella count, Escherichia coli count and coliform count. The media used were nutrient agar, potato dextrose agar, eosin methylene blue agar, Salmonella-Shigella agar, MacConkey agar, thiosulphate citrate bile-salt sucrose agar. The pour plate technique was used for the inoculation of samples. The mean total heterotrophic bacterial count for the contaminated soil ranged from $5.65 \pm$ $0.17 \log _{10} c f u / g$ to $5.94 \pm 0.29 \log _{10} c f u / g$ while the control soil was $6.85 \pm 0.03 \log _{10} c f u / m L$. The mean fungal count ranged from $3.04 \pm 0.19 \log _{I 0} c f u / g$ to $3.64 \pm 0.41 \log _{I 0} c f u / g$ for the contaminated soil and $3.38 \pm$ $0.20 \mathrm{Log} 10 \mathrm{cfu} / \mathrm{mL}$ for control soil. Salmonella-Shigella mean count ranged from $2.30 \pm 0.09 \mathrm{Log} 10 \mathrm{cfu} / \mathrm{g}$ to 2.48 $\pm 0.07 \log _{10} c f u / g$ for the contaminated soil and $2.48 \pm 0.09 \mathrm{Log} 10 \mathrm{cfu} / \mathrm{g}$ for the control soil. Vibrio cholerae mean count for contaminated soil ranged from $2.60 \pm 0.35 \log _{10} \mathrm{cfu} / \mathrm{g}$ to $3.30 \pm 0.03 \mathrm{cfu} / \mathrm{g}$ while the control soil was $2.30 \pm 0.10 \mathrm{Log} 10 \mathrm{cfu} / \mathrm{g}$. Escherichia coli mean count for contaminated soil ranged from $3.00 \pm 0.22 \mathrm{Log}_{10} \mathrm{cfu} / \mathrm{g}$ to $3.38 \pm 0.15 \log _{10} c f u / g$ and $3.38 \pm 0.05 \log 10 \mathrm{cfu} / \mathrm{g}$ for the control soil. The coliform mean count for contaminated soil ranged from $4.53 \pm 0.11 \log _{10} c f u / g$ to $4.66 \pm 0.10 \log _{10} \mathrm{cfu} / \mathrm{g}$ and $4.40 \pm 0.024 \mathrm{Log} 10 \mathrm{cfu} / \mathrm{mL}$ for the control soil. The mean microbial counts for the lairage effluent ranged as follows total heterotrophic bacterial count, $6.39 \pm 0.10 \log _{10} c f u / m L$; fungal count, $3.28 \pm 0.03 \log _{10} c f u / m L$; Salmonella-Shigella count, $2.60 \pm 0.08 \log _{10} c f u / m L ;$ Vibrio cholerae count, $3.23 \pm 0.20 \log _{10} c f u / m L$; Escherichia coli count, $3.30 \pm$ $0.01 \log _{10} \mathrm{cfu} / \mathrm{mL}$ and coliform count, $4.74 \pm 0.09 \log _{10} \mathrm{cfu} / \mathrm{mL}$. The mean values of the physicochemical parameters for the contaminated soil were temperature, $29 \pm 1.0^{\circ} \mathrm{C} ; \mathrm{pH}, 5.8 \pm 0.5$; conductivity, $55.7 \pm$ $3.0 \mu \mathrm{S} / \mathrm{cm}$, oil and grease, $2.0 \pm 0.2 \mathrm{mg} / \mathrm{kg}$; total organic carbon, $1.66 \pm 0.1 \%$; phosphate, $1.95 \pm 0.2 \mathrm{mg} / \mathrm{kg}$; nitrate, $0.66 \pm 0.01 \mathrm{mg} / \mathrm{kg}$; sulphate, $22.5 \pm 3.0 \mathrm{mg} / \mathrm{kg}$; calcium, $303 \pm 20.0 \mathrm{mg} / \mathrm{Kg}$; magnesium, $92 \pm 3.0 \mathrm{mg} / \mathrm{kg}$, potassium, $5.0 \pm 0.5 \mathrm{mg} / \mathrm{kg}$, sodium, $0.72 \pm 0.02 \mathrm{mg} / \mathrm{Kg}$. The mean values for the control soil sample were temperature, $28 \pm 0.5^{0} \mathrm{C} ; \mathrm{pH}, 6.7 \pm 0.5 ;$ conductivity, $45.8 \pm 2.0 \mu \mathrm{S} / \mathrm{cm}$; oil and grease, $1.0 \pm 0.01 \mathrm{mg} / \mathrm{kg}$; total organic carbon, $0.88 \pm 0.02 \%$; phosphate, $0.57 \pm 0.03 \mathrm{mg} / \mathrm{kg}$; nitrate, $0.30 \pm 0.01 \mathrm{mg} / \mathrm{kg} ;$ sulphate, $12.74 \pm$ $1.0 \mathrm{mg} / \mathrm{kg} ;$ calcium, $148 \pm 10.0 \mathrm{mg} / \mathrm{kg} ;$ magnesium, $81 \pm 2.0 \mathrm{mg} / \mathrm{kg} ;$ potassium, $2.0 \pm 0.1 \mathrm{mg} / \mathrm{kg} ;$ sodium, \pm $0.02 \mathrm{mg} / \mathrm{Kg}$. The mean values for the lairage effluent were temperature, $30 \pm 2.0^{\circ} \mathrm{C} ; \mathrm{pH}, 7.8 \pm 1.0$; conductivity, $40.8 \pm 4.0 \mu \mathrm{S} / \mathrm{cm}$; turbidity, $72.0 \pm 4.0 \mathrm{NTU}$; chloride, $8.0 \pm 0.5 \mathrm{mg} / \mathrm{L}$; dissolved oxygen, $1.2 \pm 0.3 \mathrm{mg} / \mathrm{L}$; biochemical oxygen demand, $36.0 \pm 5.0 \mathrm{mg} / \mathrm{L}$; chemical oxygen demand, $82.0 \pm 10.0 \mathrm{mg} / \mathrm{L}$; total suspended solids, $63.0 \pm 8.0 \mathrm{mg} / \mathrm{L}$; total dissolved solids, $24.0 \pm 2.0 \mathrm{mg} / \mathrm{L}$; nitrate, $0.85 \pm 0.03 \mathrm{mg} / \mathrm{L}$; sulphate, $1.0 \pm$ $0.05 \mathrm{mg} / \mathrm{L}$; phosphate, $2.2 \pm 0.5 \mathrm{mg} / \mathrm{L}$ and ammonia, $0.830 .02 \mathrm{mg} / \mathrm{L}$. The lairage effluent from this result is responsible for the contamination of the soil.
\end{abstract}

Key words: Microbiological, physicochemical, lairage, effluent, soil, contaminated, assessment.

\section{Introduction}

Lairage is the animal handling facilities at sales yards or abattoirs which includes load ramps, laneways, branding and injection chutes, weigh scales, holding pens, drafting races, covered housing, water points and feed bunkers (Blood et al., 2003). Animal Welfare Officers monitor the unloading of cattle into the lairage to ensure that none is injured or sick. They are penned by delivery batch to avoid the mixing and distress of cattle from more than one farm. Each animal is assessed for healthiness and hide cleanliness by the onsite official Veterinarian before lairage operators read and record Ear Tag Numbers and passport details into the computer system. With all details recorded the cattle are then processed into the abattoir (Quality Jasper Food, 2007). The lairage is more a less the abattoir. An abattoir also known as slaughterhouse is a facility where animals are killed for consumption as various types of food products. They act as the starting point of the meat processing industry, where stock comes from market or farms to enter the food chain. 
An abattoir operative's first contact with the animals scheduled for slaughter is made when the livestock is unloaded from the trailer or lorry they have been transported on (John, 2013). Waste from the lairage or slaughter-house can be grouped into two main groups: "effluent-based wastes" and "animal-based wastes". The effluent-based wastes include three main types: separated solids, sludge and water. Approximately $68 \%$ of surveyed lairages apply one or more types of effluent based-wastes to land sometimes pre-treated but most times untreated. Mixing sludge and blood is a regular practice at poultry-only abattoirs. Some of the above abattoirs also dispose separated effluent solids on land, either alone or as mixed with other types of wastes. Animal-based wastes include: digestive tract content based waste and blood based wastes. These two classes of animal-based waste arises from lairage wastes mixed with lorry waste and/or with some other waste type, lairage-only waste, stomach content waste, blood waste (either alone or mixed with sludge), (Nicholson et al., 1999, Food Standard Agency, 2013).

Human activities in many parts of the world, e.g., animal production, still impact negatively on the environment and biodiversity. Some of the consequences of man-made pollution include transmission of diseases by water borne pathogens, eutrophication of natural water bodies, accumulation of toxic or recalcitrant chemicals in the soil, destabilization of ecological balance and negative effects on human health (Amisu et al., 2003).

The continuous drive to increase meat production for the protein needs of the ever increasing world population has some pollution problems attached. The meat industry uses large quantity of wastewater that drains into surrounding soil environment (Hinton et al., 2000; Amisu et al., 2003). The effect is logging of contaminated water in the soil which results in the depletion of soil oxygen thereby making oxygen becomes less available as an electron acceptor. This prompts denitrifying bacteria to reduce available nitrate into gaseous nitrogen which enters the atmosphere with resultant negative effects. The anaerobic archaea (methanogens) may also produce excessive methane at a higher rate than aerobic methane oxidizing bacteria (methanotrophs) could cope with, thus contributing to green house effect and global warming. This gives serious concern because increase in methane is five times more effective as a green house gas than $\mathrm{CO}_{2}$ (Madigan et al., 2003; Tortora, 2007). Leaching into groundwater is a major part of the concern, especially due to the recalcitrant nature of some contaminants (Tortora et al., 2007).

Different methods of waste treatment have been developed, for reasons of public health and conservation, which results in the destruction of pathogens and the mineralization of the organic components of sewage prior to discharge. Anaerobic wastewater treatment using granular sludge reactor is one of such methods. The discharge of untreated wastes into the environment in Nigeria is still a problem, despite the establishment of Federal Environmental Protection Agency (FEPA) since 1998 (Adeyemo, 2003). Different types of animals are usually slaughtered in the studied abattoir, with their blood, part of the dung and abdominal content washed on cemented pavements. The wastewater runs through open drainage of the abattoir to bigger adjoining drainages in the neighborhood without any treatment. Part of the wastewater is washed directly to the soil within the neighborhood and may affect the whole biological community, including species diversity and contaminant accumulation in the food chain.

This aim of this study is to determine the microbiological and physicochemical characteristics of the soil contaminated with the effluent from the abattoir.

\section{Materials and Methods}

\section{Area of Study}

Ubakala is the headquarters of Umuahia South Local Government of Abia State, Nigeria and is located in the South East geopolitical zone of Nigeria. The area was chosen for the study because it serves as the sole cattle market and abattoir in Umuahia and is responsible for $65 \%$ of beef production in Umuahia and environs.

\section{Sample Collection}

The lairage effluent, contaminated soil and control soil samples were collected. The soil samples were collected in sterile plastic bags while the effluent samples were collected from the abattoir with $250 \mathrm{ml}$ sterile bottles. The bottles were used to draw part of the wastewater running into the drainage system just as it was leaving the slaughter pavements. All the samples were transported to the Microbiology Laboratory College of Natural Sciences of Michael Okpara University of Agriculture, Umudike, Abia State, Nigeria in an ice parked cooler for analyses. They were immediately analyzed on reaching the laboratory.

\section{Chemical Reagents}

Chemical reagents used in the study were of analytical grade and were products of Hach Company, Colorado, USA; BDH Chemicals, Poole's, England and Sigma Chemical Company, St. Louis Missouri, USA. The microbiological media used were products of Oxoid and Difco Laboratories England. They were nutrient agar used for the estimation of total heterotrophic aerobic bacteria, purification and for stock culture; Sabouraud 
dextrose agar used for the isolation of fungi, Salmonella-Shigella agar for the isolation of Salmonella and Shigella, thiosulphate citrate bile salt sucrose agar for the isolation of Vibrio cholerae, eosin methylene blue agar for the isolation of Escherichia coli and MacConkey agar for coliform counts.

\section{Enumeration of Total Heterotrophic Bacteria and Fungi}

Samples of the lairage effluent, contaminated soil and control soil were serially diluted in ten folds. Total viable heterotrophic aerobic bacterial and fungal counts were determined using pour plate technique. Then the molten nutrient agar, Sabouraud dextrose agar, Salmonella-Shigella agar, thiosulphate citrate bile salt sucrose agar, MacConkey agar and eosin methylene blue agar at $45^{\circ} \mathrm{C}$ were poured into the Petri dishes containing $1 \mathrm{~mL}$ of the appropriate dilution for the isolation of the total heterotrophic bacteria and fungi, Salmonella-Shigella, Vibrio cholerae, coliforms and Escherichia coli respectively. They were swirled to mix and colony counts were taken after incubating the plates at $30^{\circ} \mathrm{C}$ for $48 \mathrm{~h}$ and preserved by sub culturing the bacterial isolates into nutrient agar slants which were used for biochemical tests.

\section{Characterization and Identification of Bacterial and Fungal Isolates}

Bacterial isolates were characterized and identified after studying the Gram reaction as well as cell micro morphology. Other tests performed were spore formation, motility, oxidase and catalase production; citrate utilization, oxidative/fermentation $(\mathrm{O} / \mathrm{F})$ utilization of glucose; indole and coagulase production, starch hydrolysis, sugar fermentation, methyl red-Voges Proskaur reaction and urease production. The tests were performed according to the methods of (Cheesbrough, 2005; Adeoye, 2007; Agwung-Fobellah and Kemajou, 2007; Ochei and Kolhatkar, 2008). Microbial identification was performed using the keys provided in the Bergey's Manual of Determinative Bacteriology (1994).

Fungal isolates were examined macroscopically and microscopically using the needle mouth technique. Their identification was performed according to the scheme of Barnett and Hunter (1972) and Larone (1986).

\section{Determination of the Physiochemical Parameters}

A number of physicochemical parameters of the contaminated and control soil and lairage effluent samples were determined. They included temperature, dissolved oxygen, $\mathrm{pH}$, total dissolved solids, total suspended solids, turbidity, conductivity, nitrate, phosphate, sulphate. Others included biochemical oxygen demand, chemical oxygen demand, oil and grease, total organic carbon and exchangeable cations. The $\mathrm{pH}$ was measured using Hach $\mathrm{pH}$ meter (Model EC1O); temperature, total dissolved solids and conductivity were measured using Hach conductivity meter (Model CO150). The dissolved oxygen was also measured in-situ using Hach DO meter (Model DO175). Chemical oxygen demand and biochemical oxygen demand were determined using Walkley and Black dichromate reflux and Azide modification methods respectively. Sulphate, nitrate and phosphate were determined using Barium chloride (Turbidimetric), Cadmium reduction and Ascorbic acid methods respectively. All analyses were in accordance with APHA (2005).

\section{Determination of oil and grease}

The method was adopted from ASTM (2003). The soil samples were air dried and sieved. Ten grams of the air dried sieved samples were weighed into $60 \mathrm{ml}$ glass bottles and $20 \mathrm{ml}$ of tetrachloroethylene was poured into the glass bottles. These bottles were placed into a shaker maintained at room temperature. The system was allowed to shake for 30minutes after which they were allowed to settle. The extracts were filtered out into a $20 \mathrm{ml}$ glass bottle using a glass funnel stuffed with cotton wool on which anhydrous sodium sulphate was placed. Analysis of the samples was done using Hach DR4000 spectrophotometer.

\section{Determination of total organic carbon}

The method used was adopted from ASTM (2003). One gram each of the air-dried samples was weighed out in duplicate and transferred to $250 \mathrm{~mL}$ Erlenmeyer flask. Ten millimeters of $1 \mathrm{~N}$ potassium dichromate solution and $20 \mathrm{~mL}$ concentrated sulphuric acid was added and the flasks swirled until the soil and reagents were mixed. The flasks were allowed to stand on the sheet of asbestos for about 30 minutes after $100 \mathrm{~mL}$ of distilled water was added. Three drops of indicator was added and then titrated with $0.5 \mathrm{~N}$ ferrous sulphate solution. The endpoint was observed when the colour changed sharply from blue to red (maroon colour) in reflected light against a white background.

\section{Determination of Exchangeable Cations}

The method for the determination was adopted from APHA (2005). The soil samples were first extracted using IN ammonium acetate solution. This was done by weighing $5 \mathrm{~g}$ of sieved air dried samples and adding to $30 \mathrm{ml}$ of the extracting solution in a tube. This was shaken on a mechanical shaker for two hours. They were then centrifuged for five minutes and the supernatant carefully decanted into a $100 \mathrm{~mL}$ volumetric flask. 
This was then made up to the mark with the extracting solution. The exchangeable cations $\left(\mathrm{Na}, \mathrm{K}, \mathrm{Ca}^{2+}, \mathrm{Mg}^{2+}\right)$ of the extract were determined using Unicam Atomic Absorption Spectrophotometer, Model 969

\section{Results}

The microbiological and physicochemical analysis results are represented in Tables 1,2 and 3.

Table 1 shows the mean counts of microorganisms isolated from the contaminated and control soil and lairage effluent samples. The mean total heterotrophic bacterial count for the contaminated soil ranged from $5.65 \pm 0.17 \log _{10} \mathrm{cfu} / \mathrm{g}$ to $5.94 \pm 0.29 \log _{10} \mathrm{cfu} / \mathrm{g}$ while the control soil was $6.85 \pm 0.03 \log _{10} \mathrm{cfu} / \mathrm{mL}$. Sample A had the highest count of $5.94 \pm 0.29 \log _{10} \mathrm{cfu} / \mathrm{g}$ while sample $\mathrm{D}$ had the least count of $5.65 \pm 0.17 \log _{10} \mathrm{cfu} / \mathrm{g}$. The mean fungal count ranged from $3.04 \pm 0.19 \log _{10} \mathrm{cfu} / \mathrm{g}$ to $3.64 \pm 0.41 \log _{10} \mathrm{cfu} / \mathrm{g}$ for the contaminated soil and $3.38 \pm 0.20 \log 10 \mathrm{cfu} / \mathrm{mL}$ for control soil. Sample D had the highest count of $3.64 \pm 0.41 \log _{10} \mathrm{cfu} / \mathrm{g}$ while sample C had the least count of $3.04 \pm 0.19 \log _{10} \mathrm{cfu} / \mathrm{g}$. Salmonella-Shigella mean count ranged from $2.30 \pm$ $0.09 \log 10 \mathrm{cfu} / \mathrm{g}$ to $2.48 \pm 0.07 \log _{10} \mathrm{cfu} / \mathrm{g}$ for contaminated soil and $2.48 \pm 0.09 \log 10 \mathrm{cfu} / \mathrm{mL}$ for the control soil. The highest count was recorded in sample A while the least count was recorded in sample C. Vibrio cholerae mean count for contaminated soil ranged from $2.60 \pm 0.35 \log _{10} \mathrm{cfu} / \mathrm{g}$ to $3.30 \pm 0.03 \mathrm{cfu} / \mathrm{g}$ while the control soil was $2.30 \pm 0.10 \log 10 \mathrm{cfu} / \mathrm{mL}$. The highest count was recorded in sample A while sample D recorded the least count. Escherichia coli mean count for contaminated soil ranged from $3.00 \pm 0.22 \mathrm{Log}_{10} \mathrm{cfu} / \mathrm{g}$ to $3.38 \pm 0.15 \log _{10} \mathrm{cfu} / \mathrm{g}$ and $3.38 \pm 0.05 \mathrm{Log} 10 \mathrm{cfu} / \mathrm{mL}$ for the control soil. Sample D had the highest count of $3.38 \pm 0.15 \log _{10} \mathrm{cfu} / \mathrm{g}$ while sample $\mathrm{C}$ had the least count of $3.00 \pm 0.22 \log _{10} \mathrm{cfu} / \mathrm{g}$. The coliform mean count for contaminated soil ranged from $4.53 \pm 0.11 \log _{10} \mathrm{cfu} / \mathrm{g}$ to $4.66 \pm 0.10 \log _{10} \mathrm{cfu} / \mathrm{g}$ and $4.40 \pm$ $0.024 \log 10 \mathrm{cfu} / \mathrm{mL}$ for the control soil. The highest mean count of $4.66 \pm 0.10 \log _{10} \mathrm{cfu} / \mathrm{g}$ was recorded in sample B while the least count of $4.53 \pm 0.11 \log _{10} \mathrm{cfu} / \mathrm{g}$ was recorded in sample C. The mean microbial counts for the lairage effluent ranged as follows total heterotrophic bacterial count, $6.39 \pm 0.10 \log _{10} \mathrm{cfu} / \mathrm{mL}$; fungal count, $3.28 \pm 0.03 \log _{10} \mathrm{cfu} / \mathrm{mL}$; Salmonella-Shigella count, $2.60 \pm 0.08 \mathrm{Log}_{10} \mathrm{cfu} / \mathrm{mL}$; Vibrio cholerae count, $3.23 \pm 0.20 \log _{10} \mathrm{cfu} / \mathrm{mL} ;$ Escherichia coli count, $3.30 \pm 0.01 \log _{10} \mathrm{cfu} / \mathrm{mL}$ and coliform count, $4.74 \pm$ $0.09 \log _{10} \mathrm{cfu} / \mathrm{mL}$. The ANOVA, $\mathrm{P}<0.05$, showed that there was significant difference in the mean count of the total heterotrophic bacterial count, fungal count and Vibrio cholerae count among the contaminated soil while ANOVA, $\mathrm{P}>0.05$ showed that there was no significant difference in the mean counts Salmonella-Shigella count, Escherichia coli count and coliform count among the contaminated soil sites.

Table 2 shows the microorganisms isolated and their percentage occurrence. Bacteria isolated were Escherichia coli, 15.38\%; Enterobacter species, 11.54\%; Bacillus species, 26.92\%; Pseudomonas aeruginosa, 19.23\%; Streptococcus faecalis, 5.77\%; Staphylococcus aureus, 9.62\%; Vibrio cholerae, 7.69\% and Salmonella species, 3.85\%. Bacillus species had the highest occurrence of $26.9 \%$ while Salmonella species had the lowest occurrence of 3.85\%. Fungi isolated were Aspergillus species, 36.36\%; Penicillium species, 18.18\%; Mucor species, 21.21\%; Trichoderma species, 9.09\%; and Saccharomyces species, 15.15\%. Aspergillus species had the highest occurrence of $36.36 \%$, while, Trichoderma species had the lowest occurrence of $9.09 \%$.

The physiochemical parameters of the contaminated and control soil samples and lairage effluent are shown in Table 3. The mean values for the contaminated soil sample were temperature, $29 \pm 1.0^{\circ} \mathrm{C} ; \mathrm{pH}, 5.8 \pm$ 0.5 ; conductivity, $55.7 \pm 3.0 \mu \mathrm{S} / \mathrm{cm}$, oil and grease, $2.0 \pm 0.2 \mathrm{mg} / \mathrm{kg}$; total organic carbon, $1.66 \pm 0.1 \%$; phosphate, $1.95 \pm 0.2 \mathrm{mg} / \mathrm{kg}$; nitrate, $0.66 \pm 0.01 \mathrm{mg} / \mathrm{kg}$; sulphate, $22.5 \pm 3.0 \mathrm{mg} / \mathrm{kg}$; calcium, $303 \pm 20.0 \mathrm{mg} / \mathrm{Kg}$; magnesium, $92 \pm 3.0 \mathrm{mg} / \mathrm{kg}$, potassium, $5.0 \pm 0.5 \mathrm{mg} / \mathrm{kg}$. The mean values for the control soil sample were temperature, $28 \pm 0.5^{\circ} \mathrm{C} ; \mathrm{pH}, 6.7 \pm 0.5$; conductivity, $45.8 \pm 2.0 \mu \mathrm{S} / \mathrm{cm}$; oil and grease, $1.0 \pm 0.01 \mathrm{mg} / \mathrm{kg}$; total organic carbon, $0.88 \pm 0.02 \%$; phosphate, $0.57 \pm 0.03 \mathrm{mg} / \mathrm{kg}$; nitrate, $0.30 \pm 0.01 \mathrm{mg} / \mathrm{kg}$; sulphate, $12.74 \pm$ $1.0 \mathrm{mg} / \mathrm{kg}$; calcium, $148 \pm 10.0 \mathrm{mg} / \mathrm{kg}$; magnesium, $81 \pm 2.0 \mathrm{mg} / \mathrm{kg}$; potassium, $2.0 \pm 0.1 \mathrm{mg} / \mathrm{kg}$. The mean values for the lairage effluent were temperature, $30 \pm 2.0^{0} \mathrm{C} ; \mathrm{pH}, 7.8 \pm 1.0$; conductivity, $40.8 \pm 4.0 \mu \mathrm{S} / \mathrm{cm}$; turbidity, $72.0 \pm 4.0 \mathrm{NTU}$; chloride, $8.0 \pm 0.5 \mathrm{mg} / \mathrm{L}$; dissolved oxygen, $1.2 \pm 0.3 \mathrm{mg} / \mathrm{L}$; biochemical oxygen demand, $36.0 \pm$ $5.0 \mathrm{mg} / \mathrm{L}$; chemical oxygen demand, $82.0 \pm 10.0 \mathrm{mg} / \mathrm{L}$; total suspended solids, $63.0 \pm 8.0 \mathrm{mg} / \mathrm{L}$; total dissolved solids, $24.0 \pm 2.0 \mathrm{mg} / \mathrm{L}$; nitrate, $0.85 \pm 0.03 \mathrm{mg} / \mathrm{L}$; sulphate, $1.0 \pm 0.05 \mathrm{mg} / \mathrm{L}$; phosphate, $2.2 \pm 0.5 \mathrm{mg} / \mathrm{L}$ and ammonia, $0.830 .02 \mathrm{mg} / \mathrm{L}$.

\section{Discussion}

The mean total bacterial count and fungal count were high for contaminated soil and effluent samples from the abattoir of study. It was observed that the contaminated soil had higher microbial load than the control. This may be because the effluent contains some nutrients which can be utilized by microorganisms in the contaminated soil that are lacking in the control soil. This could also be regarded as the destabilization of the ecological balance due to the discharge of the lairage effluent. The result is in line with the reports of Adesemonye et al. (2006) and Rabah et al. (2010). The contamination of the effluent shows that any water contaminated to this level is neither good for domestic use and it is not supposed to be discharged directly into the environment without treatment. This could be as a result of failure in adhering to Good Manufacturing 
Practices (GMP) and Good Hygiene Practices (GHP). Consideration is hardly given to safety practices during animal transport to the abattoir, during slaughter and during dressing. Negligence to these safety practices often lead to contaminations from hides, hooves and content of alimentary tract during evisceration and negatively impact on the environment which includes microorganisms in the soil, soil surface and ground water (Hinton et al., 2000; Amisu et al., 2003).

The microorganisms isolated were Escherichia coli, Enterobacter species, Bacillus species, Pseudomonas species, Staphylococcus aureus, Streptococcus faecalis, Vibrio cholerae, Salmonella species, Aspergillus species, Penicillium species, Mucor species, Trichoderma species and Saccharomyces species. This is in line with the works of Ezeronye and Ubalua (2005) and Adesemonye et al. (2006). The presence of Bacillus is a well known indigenous and persistent bacteria to soil environment (Atlas and Bartha, 2007; Rabah et al., 2010). The presence of Escherichia coli, Enterobacter species, Streptococcus faecalis, Vibrio cholerae and Salmonella species in the contaminated soil may be as a result of large quantity of animal excreta in the effluent containing these organisms being discharged into the soil environment. Similar findings were reported by Ezeronye and Ubalua, (2005); Bala (2006) and Rabah et al. (2010). The fungi identified are well known soilinhabiting microorganisms as well as common spoilage organisms associated with beef industry. Their presence indicates possible pollution and may have an effect on the soil ecological balance (Alonge, 1991, Adesemoye et al., 2006; Ogbonna and Igbenijie, 2006).

The changes in the physicochemical were as a consequence of the build up in the of the breakdown product of the effluent. The mean values of the physicochemical parameters were higher in the contaminated soil samples than in control soil samples although the values were within Department of Petroleum Resources limit for discharge into the environment. The $\mathrm{pH}$ values of the samples were low while the temperature values did not show much fluctuation. The two parameters play a role in determining both the qualitative and quantitative abundance of microorganisms in the contaminated soil (Edward, 1990). The bacteria have limited tolerance for acid condition and fungi are more tolerant (Alexander, 1981). It could be inferred then, that more hydrogen ion became available; lowering the $\mathrm{pH}$ value of contaminated soil and affecting the pattern of microbial population. An increase in the exchangeable cations $\left(\mathrm{Na}^{+}, \mathrm{K}^{+}, \mathrm{Ca}^{2+}, \mathrm{Mg}^{2+}\right)$ is a reflection of increased soil conditions with regard to the agricultural potential of soils at the study sites. Such changes in soil condition are favourable since they promote the increase of organic colloids and humic acids and better nutrient availability (Bleams et al., 1987, Eze et al., 2012). The nitrate, phosphate and sulphate were higher in contaminated soil than the control soil. The increase in the sulphate content can be attributed to the fact that as sulphate is being removed from the soil, it is being replaced. Thiobacillus species oxidize $\mathrm{H}_{2} \mathrm{~S}$ and other sulphur compounds and because they have a low acid tolerance, deposit elemental sulphur rather than generate sulphuric acid by further oxidation. Other members of the genus Thiobacillus produce sulphate from the oxidation of elemental sulphur and other organic sulphur compounds (Kuenem et al., 1985, Eze and Ikeri, 2010). Phosphorus is not an abundant component of the ecosphere (Atlas and Bartha, 2007) and its availability can further be restricted by its tendency to precipitate in the presence of bivalent metals $\left(\mathrm{Ca}^{2+}, \mathrm{Mg}^{2+}\right)$ and ferric $\left(\mathrm{Fe}^{3+}\right)$ ion at neutral to alkaline $\mathrm{pH}$. Phosphates are combined with calcium within many habitats rendering them insoluble and unavailable to plants. Many microorganisms are also capable of solubilizing phosphates from such sources and assimilate and release them for use by other organisms (Atlas and Bartha, 2007). Nitrogen is an important constituent of protein and nucleic acid and most microorganisms and plants take up inorganic nitrogen as nitrate $\left(\mathrm{NO}_{3}{ }^{-}\right)$or ammonium $\left(\mathrm{NH}_{4}{ }^{+}\right)$ions. It has been shown that nitrogen can be lost from the soil because some species of bacteria convert nitrate to gaseous nitrogen by using nitrate as a metabolic electron acceptor in place of oxygen (Nester et al., 2001). Nitrates are important nutrient in the soil and can cause eutrophication in aquatic environment.

Based on findings from this research work, it has been shown that the lairage effluent is responsible for the contamination of soil within its vicinity. The government should therefore build standard abattoirs with state of art facilities such good water supply, efficient water treatment plant, for treating effluent before disposal into the environment. It is also necessary that officials of the Ministry of Health should visit the abattoirs more often to inspect the sanitary conditions and mete out punishment to offenders who fail to keep the lairage environment clean. Lastly, beef and other beef products should be properly cooked to reduce risk of transmission of contagious diseases before consumption.

\section{Conclusion}

The high level of contamination of the abattoir effluent as revealed in this study has confirmed the dangers associated with discharging untreated wastewater to the environment. There is therefore the need for adequate treatment of the effluent to avoid contamination of the abattoir premises and possible pollution of the surrounding aquatic and terrestrial environments. As abattoirs are often used for the boning, cleaning and dressing livestock, in addition to animal slaughter, there is a great need for cleanliness and avoidance of crosscontamination. 


\section{References}

[1] Adeoye, A. (2007). Medical Laboratory Practice, $1^{\text {ST }}$ edition FEMCO Publishers Limited, Lagos, Nigeria, p 153

[2] Adesemoye, A.O., Opere, B.O. and Makinde, S.C.O. (2006). Microbial content of abattoir wastewater and its contaminated soil in Lagos, Nigeria; Afr. J. Biotechnol.; 5(20): 1963-1968

[3] Adeyemo, O.K. (2003). Consequences of pollution and degradation of Nigerian aquatic environment on fisheries resources. The Environmentalist 23: 297-306.

[4] Agwng-Fobellah, D. and Kemajou, S.T. (2007). Laboratory Microbiology and Activity manual. Ark of the Wisdom Publisher, Aba, Nigeria $\mathrm{p} 153$

[5] Alonge, D.O. (1991). Testbook of meat hygiene in the Tropics. Farmcoe Press, Ibadan, p 58.

[6] American Public Health Association (APHA) (2005). Standard Methods for the Examination of Water and Wastewater. American Public Health Association, American Water Works Association and Water Pollution Control Federation. 20th edn. Washington DC, USA, Pp 5-17.

[7] Amisu, K.O, Coker, A. O, On SLW, Isokpehi RD (2003). Arcobacter butzlieri strains from poultry abattoir effluent in Nigeria. East Afri. Med. J.; 80: 218-221.

[8] American standard for Testing and Materials (ASTM) (2003). Standard Methods for the Examination of Water and Wastewater, Washington DC.

[9] Atlas R.M. and Bartha, R. (2007). Microbial Ecology Fundamentals and Applications, Benjamin/Cumming Publishing Company, Inc., Menlo Park, California

[10] Bala, J.D. (2006). Occurrence of faecal coliforms in water sources in Jimeta-Yola, Nig. J. Environ. Sci.; 10(2): 64-69.

[11] Barnett, H.L. and Hunter, B.B. (1972). Illustrated genera of imperfecti fungi, $3^{\text {rd }}$ edition, Burgess Publishing Company, Minnesota, U.S.A.

[12] Bergey's Manual of Determinative Bacteriology (1994). $9^{\text {th }}$ edition, Holt, J.D. (Ed.), Williams Wilkins CO. Baltimore, p 783.

[13] Bleams, R.L., Kuei-Mei, M. and Pirnik (1987). A review of microbial polynuclear aromatic and chlorinated hydrocarbon degradation, J. Amer. Chem.Soc.

[14] Blood, D.C., Studdent, V.P. and Gay, C.C. (2003). Saunders Comprehensive Veterinary Dictionary, $3^{\text {rd }}$ edition, Saunders Elsevier, St. Louis, Missouri, USA.

[15] Cheesebrough, M. (2006). District laboratory practice in tropical countries. Part 2. Low Price Edition. Cambridge University Press, London, p 26.

[16] Department of Petroleum Resources (DPR) (2002). Environmental Guidelines and Standards for the Petroleum Industry in Nigeria

[17] Edward, C. (1990). Microbiology of extreme environments, $2^{\text {nd }}$ edition. Open University Press, Milton Keynes.

[18] Eze, V.C. and Ikeri, E.P. (2010). Enumeration and characterization of microorganisms involved in the degradation of abattoir waste in Port Harcourt. Int'1 J. Current Res.; 6: 053-057

[19] Eze, V.C., Agwung-Fobellah, D. and Nnaji, K. (2012). Microbiological and physicochemical characteristics of soil contaminated with used generator oil, Asian J. Sci. Technol. 4(11): 020-025.

[20] Ezeronye, O.U. and Ubalua, A.O. (2005). Studies on the effects of abattoir and industrial effluents on the heavy metals and microbial quality of Aba River in Nigeria, Afr. J. Biotechnol.; 4(3): 266-272.

[21] Food Standard Agency (2013). The levels of pathogens in abattoir wastes. Retrieved from www.foodbase.org.uk/results.php?f reprt $\mathrm{id}=183$ on September 04, 2013.

[22] Hinton, M.H., Mead, G.C. and Rowlings, C. (2000). Microbiology control in meat industry. Flair Flow Europe Technical Manual. FFE339A00 May200 (www.exp.ie/flair.html).

[23] John, A. (2013). How does an abattoir operate? Demand Media Inc.

[24] Kuenem, J.G., Roberston, L.A. and Gemerden, H.V. (1985). Microbial interactions among aerobic and anaerobic sulphur-oxidizing bacteria. Adv. Microb. Ecol. 8: 1-59.

[25] Larone, B.H. (1986). Important Fungi: A Guide to identification, Harper and Row Publishers, Hagerstown, Maryland, Pp 7-26.

[26] Madigan, M. Markinto, J.M. and Parker, J. (2003). Brock biology of microorganisms, International edition, Prentice Hall International Ltd, London, Pp 1020-1040.

[27] Nester, E.W, Anderson, D.G., Roberts, C.E., Pearsall, N.N. and Nester, M.T. (2001). Microbiology: A Human Perspective. $3^{\text {rd }}$ edition, McGraw-Hill Companies Inc. United States, p 777.

[28] Nicholson, F.A., Hutchison, M.L., Smith, K.A., Keevil, C.W., Chambers, B.J. and Moore, A. (1999). A Study on Farm Manure Applications to Agricultural Land and an Assessment of the Risks of Pathogen Transfer into the Food Chain: A Report to MAFF (FS2526). ADAS.

[29] Ochei, J.O. and Kolhatkar, A.A. (2008). Medical Laboratory Science: Theory and Practice, Tata McGraw-Hill Publishing Company Limited, New York, Pp 637-745.

[30] Ogbonna, D.N. and Igbenijie, M. (2006). Characteristics of microorganisms associated with waste collection sites in Port Harcourt City, Nig. J. Microbiol.; 20(3): 1427-143

[31] Quality Jasper Food (2007). Lairage. Retrieved from www.jaspersbeef.co.uk/lairage.htm on September 04, 2013.

[32] Rabah, A.B., Oyeleke, S.B., Manga, S.B., Hassan, L.G. and Ijah, U.J.J. (2010). Microbiological and physicochemical assessment of soil contaminated with abattoir effluents in Sokoto metropolis, Nigeria. Sci. World J.; 5(3): 1-4.

[33] Tortora, G.J. Funke, B.R. and Case, C.L. (2007). Microbiology: An Introduction. $9^{\text {th }}$ edition, Benjamin/Cummings Publishing Company Inc., California.

Table 1: The mean counts of microorganisms isolated from contaminated and control soil and effluent samples.

\begin{tabular}{lcccccc}
\hline \multicolumn{1}{c}{ Samples } & THBC & FC & SSC & VC & EC \\
\hline soil control & $4.85 \pm 0.03$ & $3.04 \pm 0.08$ & $2.48 \pm 0.09$ & $2.30 \pm 0.09$ & $3.00 \pm 0.02$ & $4.40 \pm 0.24$ \\
sample A & $5.94 \pm 0.29$ & $3.20 \pm 0.17$ & $3.08 \pm 0.09$ & $3.30 \pm 0.30$ & $3.36 \pm 0.08$ & $4.60 \pm 0.04$ \\
sample B & $5.77 \pm 0.05$ & $3.15 \pm 0.08$ & $3.00 \pm 0.09$ & $3.18 \pm 0.04$ & $3.26 \pm 0.04$ & $4.66 \pm 0.02$ \\
sample C & $5.93 \pm 0.30$ & $3.41 \pm 0.19$ & $2.90 \pm 0.09$ & $2.70 \pm 0.25$ & $3.34 \pm 0.27$ \\
sample D & $5.65 \pm 0.17$ & $3.64 \pm 0.41$ & $2.78 \pm 0.09$ & $2.60 \pm 0.35$ & $3.38 \pm 0.15$ & $4.75 \pm 0.15$ \\
Lairage Effluent & $6.39 \pm 0.10$ & $3.28 \pm 0.03$ & $3.11 \pm 0.09$ & $4.23 \pm 0.20$ & $4.30 \pm 0.08$ & $4.74 \pm 0.09$ \\
\hline
\end{tabular}

Legend: $\mathrm{THBC}=$ Total heterotrophic bacterial count, $\mathrm{VC}=$ Vibrio cholerae count, $\mathrm{FC}=\mathrm{Fungal}$ count, $\mathrm{EC}=$ Escherichia coli count, $\mathrm{SSC}=$ Salmonella-Shigella count, $\mathrm{CC}=$ Coliform count. 
Table 2: Microorganisms isolated and their percentage occurrence.

\begin{tabular}{lcc}
\hline Microorganisms & Number Isolates & \% Occurrence \\
\hline Bacterial Isolate & & 15.38 \\
Escherichia coli & 8 & 11.54 \\
Enterobacter species & 6 & 26.92 \\
Bacillus species & 14 & 19.23 \\
Pseudomonas aeruginosa & 10 & 9.62 \\
Staphylococcus aureus & 5 & 5.77 \\
Streptococcus faecalis & 3 & 7.69 \\
Vibrio cholerae & 4 & 3.85 \\
Salmonella species & 2 & 100 \\
Total & 52 & 36.36 \\
Fungal Isolate & & 18.18 \\
Aspergillus species & 12 & 21.21 \\
Penicillium species & 6 & 9.09 \\
Mucor species & 7 & 15.15 \\
Trichoderma species & 3 & 100 \\
Saccharomyces species & 5 & 33 \\
Total & 33 & \\
\hline
\end{tabular}

Table 3: The mean values of the physiochemical parameters of lairage effluent, contaminated and control

\begin{tabular}{|c|c|c|c|c|}
\hline Parameters & Lairage Effluent & Contaminated Soil & Soil control & DPR Limit \\
\hline Temperature. $\left({ }^{0} \mathrm{C}\right)$ & $30 \pm 2.0$ & $29 \pm 1.0$ & $28 \pm 0.5$ & 30 \\
\hline $\mathrm{pH}$ & $7.8 \pm 1.0$ & $5.8 \pm 0.5$ & $6.7 \pm 0.5$ & $6.0-8.5$ \\
\hline $\mathrm{TDS}(\mathrm{mg} / \mathrm{L})$ & $24.0 \pm 2.0$ & NR & NR & $<2000$ \\
\hline $\mathrm{TSS}(\mathrm{mg} / \mathrm{L})$ & $63.0 \pm 8.0$ & NR & NR & $<50$ \\
\hline Chloride (mg/L) & $8.0 \pm 0.5$ & NR & NR & NA \\
\hline $\mathrm{BOD}(\mathrm{mg} / \mathrm{L})$ & $36.0 \pm 5.0$ & NR & NR & 10 \\
\hline $\mathrm{COD}(\mathrm{mg} / \mathrm{L})$ & $82.0 \pm 10.0$ & NR & NR & 40 \\
\hline $\mathrm{DO}(\mathrm{mg} / \mathrm{L})$ & $1.2 \pm 0.03$ & NR & NR & NA \\
\hline Conductivity $(\mu \mathrm{S} / \mathrm{cm})$ & $40.8 \pm 4.0$ & $55.7 \pm 3.0$ & $45.8 \pm 2.0$ & NA \\
\hline Turbidity (NTU) & $72.0 \pm 4.0$ & NR & NR & NA \\
\hline Oil and Grease(mg/Kg) & $5.0 \pm 0.2$ & $2.0 \pm 0.2$ & $1.0 \pm 0.01$ & 10 \\
\hline Total Organic Carbon (\%) & NR & $1.66 \pm 0.1$ & $0.88 \pm 0.02$ & NA \\
\hline Phosphate(mg/L)or (mg/kg) & $2.2 \pm 0.5$ & $1.95 \pm 0.2$ & $0.57 \pm 0.03$ & 200 \\
\hline Sulphate(mg/L)or (mg/kg) & $1.0 \pm 0.05$ & $22.5 \pm 3.0$ & $12.74 \pm 1.0$ & 200 \\
\hline Nitrate $(\mathrm{mg} / \mathrm{Kg})$ & $0.85 \pm 0.03$ & $0.66 \pm 0.01$ & $0.30 \pm 0.01$ & NA \\
\hline Calcium(mg/Kg) & NR & $303 \pm 30.0$ & $148 \pm 10.0$ & 200 \\
\hline Magnesium(mg/Kg) & NR & $92 \pm 3.0$ & $81 \pm 2.0$ & 200 \\
\hline Potassium(mg/Kg) & NR & $5.0 \pm 0.05$ & $2.0 \pm 0.1$ & NA \\
\hline Sodium (mg/Kg) & NR & $0.72 \pm 0.02$ & $0.56 \pm 0.02$ & NA \\
\hline $\operatorname{Ammonia}(m g / L)$ & $0.83 \pm 0.02$ & NR & NR & 0.2 \\
\hline
\end{tabular}

Legend: NR= Not Required; NA= Not available; DPR= Department of Petroleum Resources 